\title{
Gold/monolayer graphitic carbon nitride plasmonic photocatalyst for ultrafast electron transfer in solar-to-hydrogen energy conversion
}

\author{
Zhao Mo a, Hui Xu a,*, Zhigang Chen a, Xiaojie She a, Yanhua Song b, Pengcheng Yan a, Yuanguo Xu a,

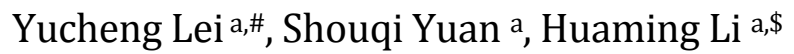 \\ a School of Materials Science \& Engineering, Institute for Energy Research, Jiangsu University, Zhenjiang 212013, Jiangsu, China \\ b School of Environmental and Chemical Engineering, Jiangsu University of Science and Technology, Zhenjiang 212003, Jiangsu, China
}

\section{A R T I C L E I N F O}

\section{Article history:}

Received 30 November 2017

Accepted 31 December 2017

Published 5 April 2018

\section{Keywords:}

Monolayer g- $\mathrm{C}_{3} \mathrm{~N}_{4}$

$\mathrm{Au}$ plasmonic nanoparticle

Photocatalytic hydrogen evolution

Hot electron

$\mathrm{Au} /$ monolayer g- $\mathrm{C}_{3} \mathrm{~N}_{4}$

\begin{abstract}
A B S T R A C T
Gold $(\mathrm{Au})$ plasmonic nanoparticles were grown evenly on monolayer graphitic carbon nitride ( $\mathrm{g}-\mathrm{C}_{3} \mathrm{~N}_{4}$ ) nanosheets via a facile oil-bath method. The photocatalytic activity of the $\mathrm{Au} /$ monolayer g- $\mathrm{C}_{3} \mathrm{~N}_{4}$ composites under visible light was evaluated by photocatalytic hydrogen evolution and environmental treatment. All of the $\mathrm{Au} /$ monolayer $\mathrm{g}-\mathrm{C}_{3} \mathrm{~N}_{4}$ composites showed better photocatalytic performance than that of monolayer g- $\mathrm{C}_{3} \mathrm{~N}_{4}$ and the $1 \% \mathrm{Au} /$ monolayer g- $\mathrm{C}_{3} \mathrm{~N}_{4}$ composite displayed the highest photocatalytic hydrogen evolution rate of the samples. The remarkable photocatalytic activity was attributed largely to the successful introduction of Au plasmonic nanoparticles, which led to the surface plasmon resonance (SPR) effect. The SPR effect enhanced the efficiency of light harvesting and induced an efficient hot electron transfer process. The hot electrons were injected from the Au plasmonic nanoparticles into the conduction band of monolayer $\mathrm{g}-\mathrm{C}_{3} \mathrm{~N}_{4}$. Thus, the $\mathrm{Au} /$ monolayer g- $\mathrm{C}_{3} \mathrm{~N}_{4}$ composites possessed higher migration and separation efficiencies and lower recombination probability of photogenerated electron-hole pairs than those of monolayer g- $\mathrm{C}_{3} \mathrm{~N}_{4}$. A photocatalytic mechanism for the composites was also proposed.
\end{abstract}

(C) 2018, Dalian Institute of Chemical Physics, Chinese Academy of Sciences. Published by Elsevier B.V. All rights reserved.

\section{Introduction}

Energy crises and environmental pollution are two major challenges facing the contemporary world that force people to move away from their dependence on fossil fuels [1-3]. Hydrogen $\left(\mathrm{H}_{2}\right)$ is a source of renewable green energy that is an attractive substitute for fossil fuels. To realize the effective use of $\mathrm{H}_{2}$ energy, it is necessary to develop $\mathrm{H}_{2}$ production technolo- gies that are clean, cheap, efficient, and large-scale [4,5]. Photocatalytic $\mathrm{H}_{2}$ evolution can translate solar energy into chemical energy and has the advantages of high product purity, carbon-free environmental friendliness, simplicity, and low energy consumption, thereby making it a promising $\mathrm{H}_{2}$ production technology [6-8]. However, photocatalytic $\mathrm{H}_{2}$ evolution technology is currently limited by the low efficiency of photocatalytic $\mathrm{H}_{2}$ evolution, poor stability of the photocatalyst, and high

\footnotetext{
* Corresponding author. Tel/Fax: +86-511-88799500; E-mail: xh@ujs.edu.cn

\# Corresponding author. Tel/Fax: +86-511-88799500; E-mail: yclei@ujs.edu.cn

\$Corresponding author. Tel/Fax: +86-511-88799500; E-mail: lihm@ujs.edu.cn

This work was supported by the National Natural Science Foundation of China $(21476097,21776118)$, the Six Talent Peaks Project in Jiangsu Province (2014-JNHB-014), the Natural Science Foundation of Jiangsu Province (BK20161363), the Postgraduate Research \& Practice Innovation Program of Jiangsu Province (KYCX17-1769), and the Project Funded by the Priority Academic Program Development of Jiangsu Higher Education Institutions. DOI: 10.1016/S1872-2067(17)62978-4 | http://www.sciencedirect.com/science/journal/18722067 | Chin. J. Catal., Vol. 39 , No. 4, April 2018
} 
cost of $\mathrm{H}_{2}$ evolution $[9,10]$. Therefore, developing affordable, easily prepared photocatalysts for photocatalytic $\mathrm{H}_{2}$ evolution has attracted much attention. Metal-free semiconductor materials are desirable to realize solar energy conversion without using toxic heavy metals [11].

A representative metal-free semiconductor photocatalyst is graphitic carbon nitride $\left(\mathrm{g}-\mathrm{C}_{3} \mathrm{~N}_{4}\right)$, which has excellent physical and chemical properties, such as high chemical and thermal stability, commendable photoelectric properties, and powerful antioxidant behavior [12,13]. Importantly, g- $\mathrm{C}_{3} \mathrm{~N}_{4}$ can make use of visible light because of its suitable band gap [14]. Thus, g- $\mathrm{C}_{3} \mathrm{~N}_{4}$ has been widely applied in photocatalytic degradation, air purification, photocatalytic water splitting, and photocatalytic carbon dioxide reduction $[15,16]$. However, bulk g- $\mathrm{C}_{3} \mathrm{~N}_{4}$ possesses several disadvantages, such as low specific surface area, a high recombination rate of photogenerated electron-hole pairs, and sluggish reaction kinetics [17-19]. These disadvantages severely limit the photocatalytic activity of bulk g- $\mathrm{C}_{3} \mathrm{~N}_{4}$, so it is necessary to improve its photocatalytic performance by modification strategies such as nanostructure formation, molecular doping, construction of heterojunctions, and elemental doping [20-22]. One approach to improve the photocatalytic efficiency of g- $\mathrm{C}_{3} \mathrm{~N}_{4}$ is to exfoliate bulk g- $\mathrm{C}_{3} \mathrm{~N}_{4}$ into monolayer g- $\mathrm{C}_{3} \mathrm{~N}_{4}$ nanosheets [23]. At present, there are two main exfoliation methods of $\mathrm{g}-\mathrm{C}_{3} \mathrm{~N}_{4}$ : liquid exfoliation and thermal exfoliation [24]. Two-dimensional (2D) g- $\mathrm{C}_{3} \mathrm{~N}_{4}$ nanosheets possess a larger specific surface area with more active sites, higher separation efficiency of photogenerated electron-hole pairs, and increased electron transport compared with the corresponding properties of bulk g- $\mathrm{C}_{3} \mathrm{~N}_{4}$ [25].

Although 2D g- $\mathrm{C}_{3} \mathrm{~N}_{4}$ nanosheets display greatly improved photocatalytic performance over that of bulk g- $\mathrm{C}_{3} \mathrm{~N}_{4}$, their performance still does not meet the expectations of researchers. Therefore, massive effort has been devoted to optimizing the photocatalytic ability of $2 \mathrm{D} \mathrm{g}-\mathrm{C}_{3} \mathrm{~N}_{4}$ nanosheets [26]. Doping 2D g- $\mathrm{C}_{3} \mathrm{~N}_{4}$ nanosheets with a plasmonic metal (like $\mathrm{Au}, \mathrm{Ag}, \mathrm{Pd}, \mathrm{Pt}$, $\mathrm{Rh}$, or Ir) could further enhance its ability to absorb visible light through the surface plasmon resonance (SPR) effect, which is one of the most common and effective strategies to enhance photocatalytic activity [27-30]. As many researchers have reported [31-39], when a plasmonic metal is coupled with a semiconductor, hot electrons are generated in the plasmonic metal by overcoming the Schottky barrier under visible-light irradiation. Then, a high density of hot electrons flows into the conduction band (CB) of the semiconductor to trigger the reduction reaction, resulting in increased photocatalytic activity. Previously, our group designed a plasmonic composite consisting of $\mathrm{Ag}$ nanoparticles supported on monolayer g- $\mathrm{C}_{3} \mathrm{~N}_{4}$ nanosheets, which verified the role of the SPR effect in increasing photocatalytic activity [40]. However, the photocatalytic performance of the $\mathrm{Ag} / 2 \mathrm{D} \mathrm{g}-\mathrm{C}_{3} \mathrm{~N}_{4}$ composites was still less than ideal.

The purpose of this work is to greatly enhance the photocatalytic performance of monolayer g- $\mathrm{C}_{3} \mathrm{~N}_{4}$ and steer the flow of charge carriers by dispersing Au plasmonic nanoparticles on the surface of monolayer $\mathrm{g}-\mathrm{C}_{3} \mathrm{~N}_{4}$ nanosheets. The $\mathrm{H}_{2}$ evolution rate of the resulting $\mathrm{Au} /$ monolayer g- $\mathrm{C}_{3} \mathrm{~N}_{4}$ composites is evalu- ated. The photocatalytic mechanism of the composites is investigated by photocurrent tests.

\section{Experimental}

\subsection{Synthesis of monolayer $g-C_{3} N_{4}$}

The monolayer g- $\mathrm{C}_{3} \mathrm{~N}_{4}$ was prepared according to our previous report [23]. Melamine ( $2 \mathrm{~g}$ ) was placed in a crucible and then annealed at $550{ }^{\circ} \mathrm{C}$ for $4 \mathrm{~h}$ after heating at a rate of 2 ${ }^{\circ} \mathrm{C} / \mathrm{min}$ in a muffle furnace. The obtained sample was ground into a powder and then annealed again at $550{ }^{\circ} \mathrm{C}$ under the same conditions, the obtained white sample was monolayer g- $\mathrm{C}_{3} \mathrm{~N}_{4}$.

\subsection{Fabrication of $\mathrm{Au} /$ monolayer $g-\mathrm{C}_{3} \mathrm{~N}_{4}$ composites}

Monolayer g- $\mathrm{C}_{3} \mathrm{~N}_{4}(0.1 \mathrm{~g})$ was dissolved in water $(10 \mathrm{~mL})$ under sonication. $\mathrm{NH}_{3} \cdot \mathrm{H}_{2} \mathrm{O}(2 \mathrm{~mL}), \mathrm{Na}_{2} \mathrm{SO}_{3}(0.01 \mathrm{~g})$, and isooctane $(10 \mathrm{~mL})$ were added to the mixture. The stirred mixture was heated in an oil bath $\left(95{ }^{\circ} \mathrm{C}\right)$ for $10 \mathrm{~min}$, and then $\mathrm{HAuCl}_{4} \cdot 4 \mathrm{H}_{2} \mathrm{O}$ (0.0011, 0.0021 , or $0.0042 \mathrm{~g}$ ) was added dropwise. The mixture was stirred at $95{ }^{\circ} \mathrm{C}$ for $1 \mathrm{~h}$. The sample was collected by centrifugal separation and then washed several times with pure water. The $\mathrm{Au} /$ monolayer $\mathrm{g}-\mathrm{C}_{3} \mathrm{~N}_{4}$ composites were obtained by freeze-drying. The samples produced using different masses of $\mathrm{HAuCl}_{4} \cdot 4 \mathrm{H}_{2} \mathrm{O}$ of $0.0011,0.0021$, and 0.0042 g are denoted as $0.5 \%, 1 \%$, and $2 \% \mathrm{Au} /$ monolayer g- $\mathrm{C}_{3} \mathrm{~N}_{4}$, respectively.

\subsection{Characterization}

The samples were analyzed by X-ray diffraction (XRD) by Bruker D8 diffractometer with $\mathrm{Cu} K_{\alpha}$ radiation $(\lambda=1.5418 \AA)$ in the range of $2 \theta=10^{\circ}-80^{\circ}$. The structural information for samples was measured by Fourier transform infrared spectroscopy (FTIR, Avatar 470, Thermo Nicolet) using the standard KBr disk method. The morphology and structure of the samples were investigated with scanning electron microscope (SEM) and transmission electron microscopy (TEM). The SEM images were taken on a field-emission microscope by a JEOL JSM-7001F. The transmission electron microscopy (TEM) images were collected with a JEOL-JEM-2010 (JEOL, Japan) operated at $200 \mathrm{kV}$. Elemental compositions were detected by X-ray photoelectron spectroscopy (XPS) analysis which was performed on an ESCALab MKII X-ray photo-electron spectrometer using the $\mathrm{Mg} K_{\alpha}$ radiation. Ultraviolet visible (UV-vis) diffuse reflectance spectrums (DRS) of the samples were measured by using a UV-vis spectrophotometer (Shimadzu UV-2450, Japan) in the range of 200 to $800 \mathrm{~nm}$. $\mathrm{BaSO}_{4}$ was used as the reflectance standard material. The photoluminescence (PL) spectra of the samples were obtained by a QuantaMaster \& TimeMaster Spectrofluorometer with an excitation wavelength at $325 \mathrm{~nm}$. $\mathrm{X}$-band ESR spectra were recorded at ambient temperature on a JES FA200 spectrometer. The settings for the ESR spectrometer were as follows: center field, $336.496 \mathrm{mT}$; sweep width, 5 mT; microwave frequency, $9.5 \mathrm{GHz}$; modulation frequency, 100 
$\mathrm{kHz}$; power, $0.998 \mathrm{~mW}$.

\subsection{Photoelectrochemical measurements}

The photocurrent generated by the samples was tested with an electrochemical analyzer (CHI660B, Chen Hua Instruments, Shanghai, China) using a standard three-electrode configuration including a $\mathrm{Pt}$ wire counter electrode, $\mathrm{Ag} / \mathrm{AgCl}$ reference electrode, and $\mathrm{Na}_{2} \mathrm{SO}_{4}(0.1 \mathrm{~mol} / \mathrm{L})$ aqueous solution as the electrolyte. The light source was a 500-W Xe arc lamp. Each sample $(5 \mathrm{mg})$ was dispersed in ethanol $(0.5 \mathrm{~mL})$ and ethylene glycol $(0.5 \mathrm{~mL})$. Then, $20 \mu \mathrm{L}$ of each dispersion was drop-cast onto an indium tin oxide (ITO) substrate over a fixed area of 0.5 $\mathrm{cm}^{2}$. Each sample-modified ITO electrode was dried under an infrared lamp. A potential of $-0.2 \mathrm{~V}$ (vs. $\mathrm{Ag} / \mathrm{AgCl}$ ) was used in the photocurrent measurements.

\subsection{Photocatalytic activity measurements}

Photocatalytic $\mathrm{H}_{2}$ production by the samples was tested using an online photocatalytic $\mathrm{H}_{2}$ production system (LbSolar-3AG, PerfectLight, Beijing). Each sample (0.05 g) was dispersed in an aqueous solution consisting of water $(90 \mathrm{~mL})$ and hole sacrificial agent $(10 \mathrm{~mL})$. The mixtures were degassed before conducting measurements, which were performed using a 300-W Xe lamp (PLS-SXE 300C (BF), PerfectLight, Beijing)
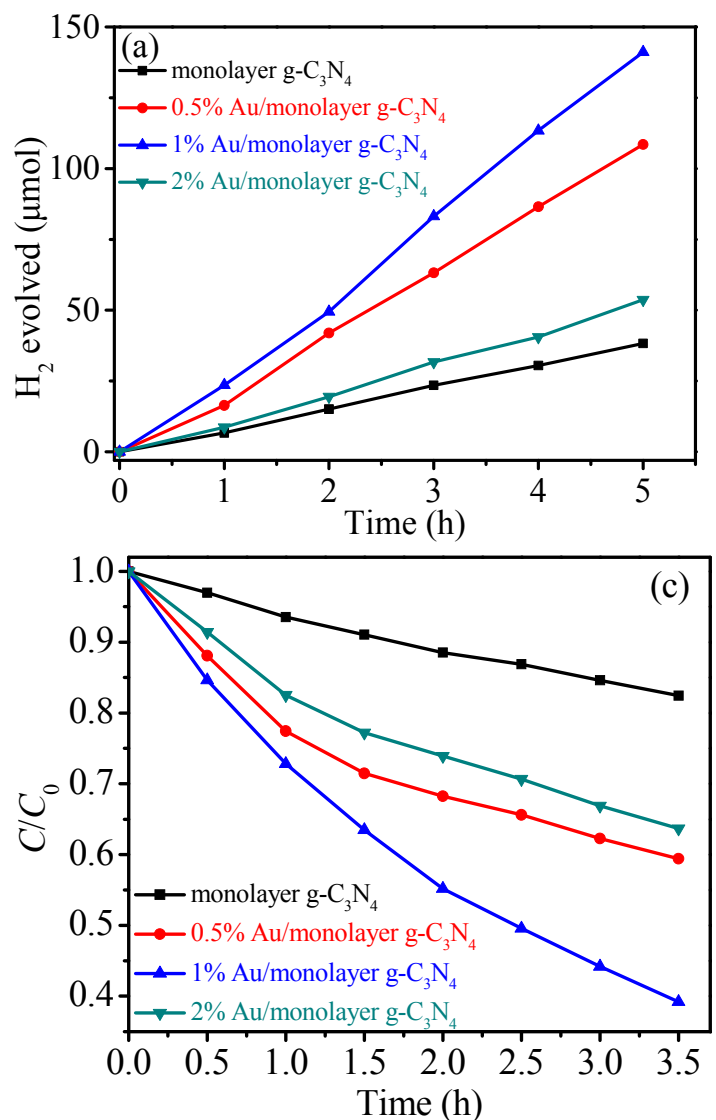

with an optical filter $(\lambda>400 \mathrm{~nm})$ as the light source. An online gas chromatograph (GC D7900P, thermal conductivity detector, nitrogen carrier gas, $5 \AA$ molecular sieve column, Shanghai Fechcomp) was used to determine the photocatalytic $\mathrm{H}_{2}$ evolution rate.

The photocatalytic activities of the samples were investigated by their photodegradation of ciprofloxacin (CIP) and methyl orange (MO) under visible-light irradiation. The light source was a $300-\mathrm{W}$ Xe lamp with a 400-nm cutoff filter. Each sample $(0.0150 \mathrm{~g})$ was dispersed in CIP or MO aqueous solution $(10 \mathrm{mg} / \mathrm{L}, 50 \mathrm{~mL})$. The reaction used a pump to provide oxygen. To ensure that absorption-desorption equilibrium was reached on the photocatalyst surface, the suspension was stirred for about $30 \mathrm{~min}$ in the dark before light exposure. The experiments were conducted under continuous stirring at 30 ${ }^{\circ} \mathrm{C}$. Every $30 \mathrm{~min}$, a $3.5 \mathrm{~mL}$ aliquot of the suspension was extracted and centrifuged. The supernatant was analyzed using a UV-vis spectrophotometer (UV-2450, Shimadzu, Japan). The contents of pollutants were determined using the maximum absorption wavelengths of CIP of $276 \mathrm{~nm}$ and of MO of $463 \mathrm{~nm}$.

\section{Results and discussion}

\subsection{Enhancement of photocatalytic activity}

Fig. 1(a) shows the photocatalytic performance of the
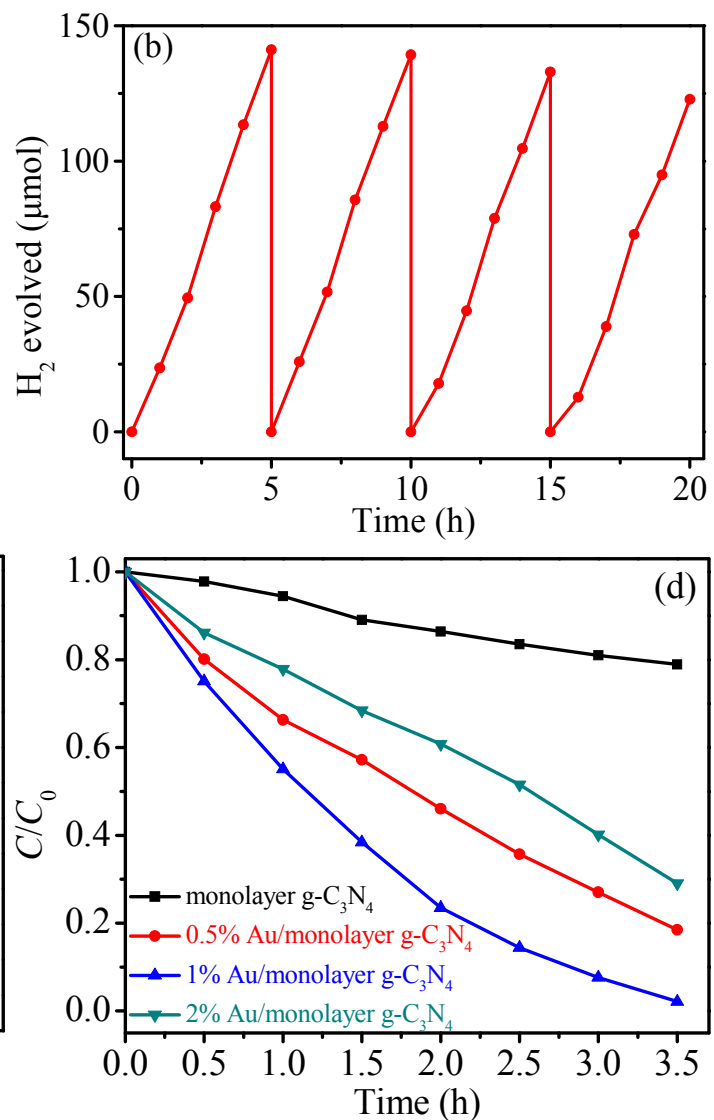

Fig. 1. (a) Photocatalytic $\mathrm{H}_{2}$ evolution by the photocatalysts $(0.05 \mathrm{~g})$ in $10 \mathrm{vol} \%$ triethanolamine aqueous solution under visible-light irradiation. (b) Stability test of $1 \% \mathrm{Au}$ /monolayer g- $\mathrm{C}_{3} \mathrm{~N}_{4}$ for $\mathrm{H}_{2}$ evolution under visible-light irradiation. Photocatalytic activity of monolayer g-C $\mathrm{C}_{3}$ and $\mathrm{Au} /$ monolayer g- $\mathrm{C}_{3} \mathrm{~N}_{4}$ composites for the degradation of CIP (c) and MO (d) under visible-light irradiation. 
$\mathrm{Au}$ /monolayer g- $\mathrm{C}_{3} \mathrm{~N}_{4}$ composites in $\mathrm{H}_{2}$ evolution from water. The pure monolayer $\mathrm{g}-\mathrm{C}_{3} \mathrm{~N}_{4}$ showed low photocatalytic $\mathrm{H}_{2}$ evolution activity under visible-light irradiation with an $\mathrm{H}_{2}$ evolution rate of $153 \mu \mathrm{mol} \mathrm{g}-1 \mathrm{~h}^{-1}$. All of the $\mathrm{Au} /$ monolayer g- $\mathrm{C}_{3} \mathrm{~N}_{4}$ composites exhibited enhanced photocatalytic activity compared with that of the pure monolayer g- $\mathrm{C}_{3} \mathrm{~N}_{4}$. In particular, the $1 \% \mathrm{Au} /$ monolayer $\mathrm{g}-\mathrm{C}_{3} \mathrm{~N}_{4}$ composite exhibited the highest $\mathrm{H}_{2}$ evolution rate of $565 \mu \mathrm{mol} \mathrm{g} \mathrm{g}^{-1} \mathrm{~h}^{-1}$, which is in line with that of previously reported $\mathrm{Au} / \mathrm{g}-\mathrm{C}_{3} \mathrm{~N}_{4}$ photocatalysts (Table S1). These results indicated that the introduction of $\mathrm{Au}$ plasmonic nanoparticles raised the photocatalytic performance of monolayer $\mathrm{g}-\mathrm{C}_{3} \mathrm{~N}_{4}$. The optimal Au content to maximize the $\mathrm{H}_{2}$ evolution rate was $1 \%$. This result indicates that a moderate amount of $\mathrm{Au}$ plasmonic nanoparticles dispersed on the surface of the monolayer g- $\mathrm{C}_{3} \mathrm{~N}_{4}$ nanosheets facilitated charge transport. Although the SPR effect of the $2 \% \mathrm{Au} /$ monolayer $\mathrm{g}-\mathrm{C}_{3} \mathrm{~N}_{4}$ should be enhanced compared with that of the composite with $1 \% \mathrm{Au}$, the number of active sites of monolayer $\mathrm{g}-\mathrm{C}_{3} \mathrm{~N}_{4}$ will decrease because Au covers more of the surface of monolayer $\mathrm{g}-\mathrm{C}_{3} \mathrm{~N}_{4}$. The excess $\mathrm{Au}$ nanoparticles do not enhance the migration and separation efficiency of photogenerated electron-hole pairs, and may serve as recombination centers of photogenerated electron-hole pairs, thus lowering the $\mathrm{H}_{2}$ evolution rate [41-43].

The performance of $\mathrm{Au} /$ monolayer $\mathrm{g}-\mathrm{C}_{3} \mathrm{~N}_{4}$ and that of previously reported $\mathrm{Ag} /$ monolayer g- $\mathrm{C}_{3} \mathrm{~N}_{4}$ are compared in Fig. S1 [40]. The $1 \% \mathrm{Au} /$ monolayer $\mathrm{g}-\mathrm{C}_{3} \mathrm{~N}_{4}$ composite showed a higher $\mathrm{H}_{2}$ evolution rate $\left(565 \mu \mathrm{mol} \mathrm{g}^{-1} \mathrm{~h}^{-1}\right.$ ) than that of $1 \%$ $\mathrm{Ag} /$ monolayer $\mathrm{g}-\mathrm{C}_{3} \mathrm{~N}_{4}\left(173 \mu \mathrm{mol} \mathrm{g}^{-1} \mathrm{~h}^{-1}\right)$, suggesting that $\mathrm{Au} /$ monolayer g- $\mathrm{C}_{3} \mathrm{~N}_{4}$ possessed higher photocatalytic activity than $\mathrm{Ag} /$ monolayer $\mathrm{g}-\mathrm{C}_{3} \mathrm{~N}_{4}$ at the same doping amount. In addition, the $\mathrm{H}_{2}$ evolution rate of $1 \% \mathrm{Au} /$ monolayer $\mathrm{g}-\mathrm{C}_{3} \mathrm{~N}_{4}$ was also higher than that of $2 \% \mathrm{Ag} /$ monolayer g- $\mathrm{C}_{3} \mathrm{~N}_{4}\left(342 \mu \mathrm{mol} \mathrm{g}^{-1}\right.$ $\mathrm{h}^{-1}$ ), which was the optimal doping amount in our previously reported system. Therefore, compared with our previously reported $\mathrm{Ag} /$ monolayer $\mathrm{g}-\mathrm{C}_{3} \mathrm{~N}_{4}$ composites, $\mathrm{Au} /$ monolayer g- $\mathrm{C}_{3} \mathrm{~N}_{4}$ displayed dramatically improved photocatalytic activity at a much lower doping amount.

The photocatalytic performance of $\mathrm{Au} /$ monolayer $\mathrm{g}-\mathrm{C}_{3} \mathrm{~N}_{4}$ composites was also evaluated by photodegradation of CIP and MO under visible-light irradiation (Fig. 1(c) and (d)). To rule out the photosensitization process of the $\mathrm{Au} /$ monolayer $\mathrm{g}-\mathrm{C}_{3} \mathrm{~N}_{4}$ composites, CIP was chosen as a model colorless organic pollutant. CIP is a widely used antibiotic. However, CIP in aquatic environments seriously threatens human health and the safety of ecosystems, so the degradation of CIP has become an important issue. As shown in Fig. 1(c), compared with that of the pure monolayer g- $\mathrm{C}_{3} \mathrm{~N}_{4}$, all of the $\mathrm{Au} /$ monolayer g- $\mathrm{C}_{3} \mathrm{~N}_{4}$ composites exhibited enhanced photocatalytic activity for CIP degradation under visible-light irradiation. This clearly indicates that the introduction of $\mathrm{Au}$ to monolayer g- $\mathrm{C}_{3} \mathrm{~N}_{4}$ enhances its photocatalytic activity. The $1 \% \mathrm{Au} /$ monolayer $\mathrm{g}-\mathrm{C}_{3} \mathrm{~N}_{4}$ exhibited the highest photocatalytic activity of the composites; its photocatalytic degradation efficiency of CIP was about $61 \%$ after irradiation for $3.5 \mathrm{~h}$, which was almost 3.4 times higher than that of pure monolayer $\mathrm{g}-\mathrm{C}_{3} \mathrm{~N}_{4}(18 \%)$. The photocatalytic degradation efficiencies of $0.5 \%$ and $2 \% \mathrm{Au} /$ monolayer $\mathrm{g}-\mathrm{C}_{3} \mathrm{~N}_{4}$ were about $41 \%$ and $36 \%$ after irradiation for $3.5 \mathrm{~h}$, respectively.

Moreover, the photocatalytic degradation of MO was investigated to further evaluate the photocatalytic activity of the $\mathrm{Au} /$ monolayer $\mathrm{g}-\mathrm{C}_{3} \mathrm{~N}_{4}$ composites; the results are presented in Fig. 1(d). After irradiation for $3.5 \mathrm{~h}$, only about $21 \%$ MO was degraded by the pure monolayer g- $\mathrm{C}_{3} \mathrm{~N}_{4}$. The photocatalytic activity increased remarkably when $\mathrm{Au}$ nanoparticles were introduced onto the monolayer g- $\mathrm{C}_{3} \mathrm{~N}_{4}$. Again, $1 \%$ $\mathrm{Au} /$ monolayer $\mathrm{g}-\mathrm{C}_{3} \mathrm{~N}_{4}$ possessed the highest photocatalytic activity of the composites; its photocatalytic degradation efficiency of MO was about $98 \%$ after irradiation for $3.5 \mathrm{~h}$. In contrast, the photocatalytic degradation efficiencies of $0.5 \%$ and $2 \% \mathrm{Au} /$ monolayer $\mathrm{g}-\mathrm{C}_{3} \mathrm{~N}_{4}$ were about $82 \%$ and $71 \%$ after irradiation for $3.5 \mathrm{~h}$, respectively. The photocatalytic degradation kinetics of the organic pollutants CIP and MO were also determined (Fig. S2).

The results of activity tests presented above indicated that the Au content of the composites had a considerable effect on their photocatalytic performance. The optimal Au content of the $\mathrm{Au} /$ monolayer $\mathrm{g}-\mathrm{C}_{3} \mathrm{~N}_{4}$ composites was approximately $1 \%$. An appropriate $\mathrm{Au}$ content dispersed well on the surface of the monolayer $\mathrm{g}-\mathrm{C}_{3} \mathrm{~N}_{4}$ to promote the separation and transfer of photoinduced charge carriers. The photocatalytic $\mathrm{H}_{2}$ evolution rate decreased when the Au content exceeded 1\% because the excess $\mathrm{Au}$ nanoparticles might function as a recombination center or cover the active sites of monolayer g- $\mathrm{C}_{3} \mathrm{~N}_{4}$, lowering its adsorption capacity, thereby decreasing the efficiency of charge separation and transfer [42,43]. Therefore, it was important to optimize the ratio of Au nanoparticles to monolayer g- $\mathrm{C}_{3} \mathrm{~N}_{4}$.

The stability and reusability of a photocatalyst are also relevant to its practical application. Therefore, recycling reactions were conducted for photocatalytic $\mathrm{H}_{2}$ evolution and the photodegradation of CIP and MO over $1 \% \mathrm{Au} /$ monolayer g- $\mathrm{C}_{3} \mathrm{~N}_{4}$ under visible-light irradiation; the results are presented in Fig. 1(b) and S3, respectively. After several continuous cycles, no obvious decay of the photocatalytic activity of $1 \%$ $\mathrm{Au} /$ monolayer $\mathrm{g}-\mathrm{C}_{3} \mathrm{~N}_{4}$ was observed, which meant that the composite had high photocatalytic stability. Furthermore, the XRD patterns of $1 \% \mathrm{Au} /$ monolayer $\mathrm{g}-\mathrm{C}_{3} \mathrm{~N}_{4}$ before and after the photocatalytic reactions (Fig. S3(c)) revealed that there was no apparent change in the crystal structure of the sample after several photocatalysis cycles. This indicates that the $\mathrm{Au} /$ monolayer $\mathrm{g}-\mathrm{C}_{3} \mathrm{~N}_{4}$ composites are very stable during the photodegradation process.

\subsection{Catalyst characterization}

XRD was used to study the crystallinity and purity of the samples. Typical diffraction patterns of monolayer g- $\mathrm{C}_{3} \mathrm{~N}_{4}$ and $\mathrm{Au} /$ monolayer g- $\mathrm{C}_{3} \mathrm{~N}_{4}$ composites are shown in Fig. 2(a). Monolayer g- $\mathrm{C}_{3} \mathrm{~N}_{4}$ exhibited a strong (002) peak at around $27.4^{\circ}$, which was attributed to the stacking of the conjugated aromatic system and confirmed that monolayer $\mathrm{g}-\mathrm{C}_{3} \mathrm{~N}_{4}$ was indeed g- $\mathrm{C}_{3} \mathrm{~N}_{4}$ [44]. The $\mathrm{Au} /$ monolayer $\mathrm{g}-\mathrm{C}_{3} \mathrm{~N}_{4}$ hybrid composites also displayed the (002) peak at the same position, suggesting that 

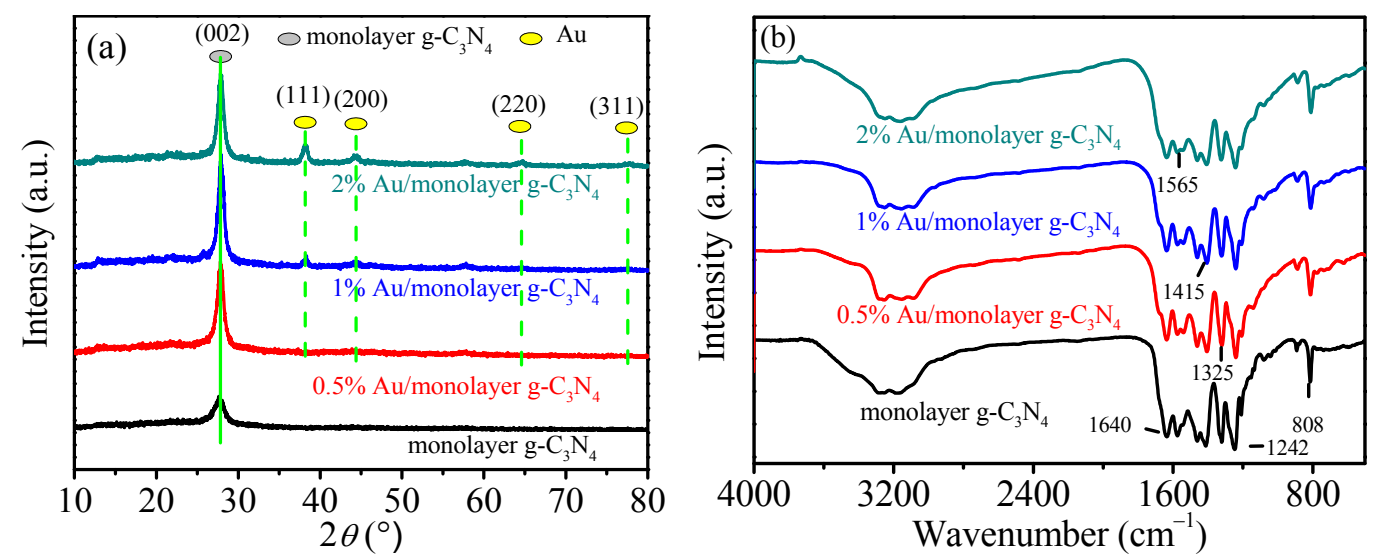

Fig. 2. XRD patterns (a) and FT-IR spectra (b) of the monolayer $\mathrm{g}-\mathrm{C}_{3} \mathrm{~N}_{4}$ and $\mathrm{Au} /$ monolayer g- $\mathrm{C}_{3} \mathrm{~N}_{4}$ composites.

the introducing of Au had no effect on the crystal structure of monolayer $\mathrm{g}-\mathrm{C}_{3} \mathrm{~N}_{4}$. Furthermore, the diffraction peaks observed at $38.2^{\circ}, 44.3^{\circ}, 64.6^{\circ}$, and $77.6^{\circ}$ in the XRD patterns of the $\mathrm{Au} /$ monolayer $\mathrm{g}-\mathrm{C}_{3} \mathrm{~N}_{4}$ composites could be assigned to the (111), (200), (220), and (311) planes of metallic Au nanoparticles, respectively [45]. With increasing Au content, the intensity of the diffraction peaks from $\mathrm{Au}$ nanoparticles increased gradually. No diffraction peaks from $\mathrm{Au}$ were detected for $0.5 \%$ $\mathrm{Au} /$ monolayer g- $\mathrm{C}_{3} \mathrm{~N}_{4}$, which was attributed to its low content of $\mathrm{Au}$.

Fig. 2(b) depicts the Fourier transform infrared (FT-IR) spectra of the monolayer g- $\mathrm{C}_{3} \mathrm{~N}_{4}$ and $\mathrm{Au} /$ monolayer $\mathrm{g}-\mathrm{C}_{3} \mathrm{~N}_{4}$ composites. The FT-IR spectra were similar for the pure mono-
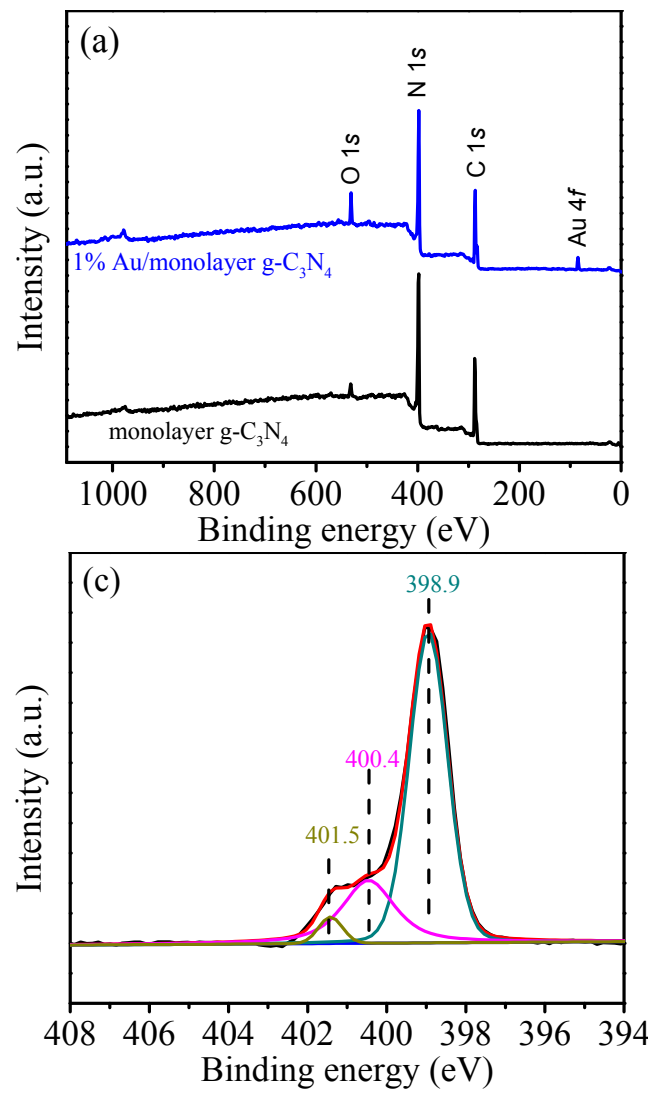

layer g- $\mathrm{C}_{3} \mathrm{~N}_{4}$ and $\mathrm{Au} /$ monolayer g- $\mathrm{C}_{3} \mathrm{~N}_{4}$ composites, which indicates that all the $\mathrm{Au} /$ monolayer $\mathrm{g}-\mathrm{C}_{3} \mathrm{~N}_{4}$ composites retained the same chemical structure as that of pure monolayer $\mathrm{g}-\mathrm{C}_{3} \mathrm{~N}_{4}$. The band at about $808 \mathrm{~cm}^{-1}$ corresponded to the characteristic breathing mode of the s-triazine units [46]. The absorption bands observed at about 1242, 1325, 1415, 1565 and 1640 $\mathrm{cm}^{-1}$ were assigned to the typical stretching vibration modes of $\mathrm{CN}$ heterocycles [47]. $\mathrm{N}-\mathrm{H}$ stretching vibrations were observed between 3600 and $3000 \mathrm{~cm}^{-1}$ [48].

The chemical composition and chemical states of monolayer g- $\mathrm{C}_{3} \mathrm{~N}_{4}$ and $\mathrm{Au} /$ monolayer $\mathrm{g}-\mathrm{C}_{3} \mathrm{~N}_{4}$ composites were further determined by X-ray photoelectron spectroscopy (XPS). Fig 3 (a) shows the survey scan of pure monolayer $\mathrm{g}-\mathrm{C}_{3} \mathrm{~N}_{4}$ and
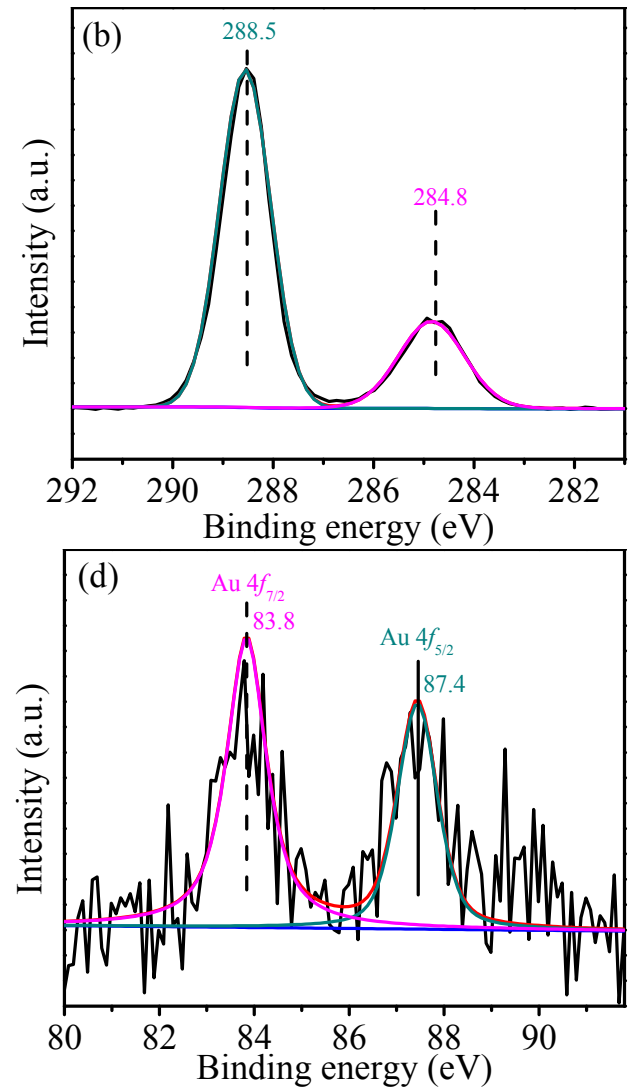

Fig. 3. XPS analysis of the pure monolayer g- $\mathrm{C}_{3} \mathrm{~N}_{4}$ and $1 \% \mathrm{Au} /$ monolayer $\mathrm{g}-\mathrm{C}_{3} \mathrm{~N}_{4}$. (a) Survey; (b) C $1 s$; (c) $\mathrm{N} 1 s$; (d) $\mathrm{Au} 4 f$. 
$\mathrm{Au} /$ monolayer g- $\mathrm{C}_{3} \mathrm{~N}_{4}$ composites; $\mathrm{C}, \mathrm{N}$, and $\mathrm{O}$ were found in the as-prepared samples. In addition, $1 \% \mathrm{Au} /$ monolayer $\mathrm{g}-\mathrm{C}_{3} \mathrm{~N}_{4}$ contained $\mathrm{Au}$. These results indicated that there were no other impurities in the $\mathrm{Au} /$ monolayer $\mathrm{g}-\mathrm{C}_{3} \mathrm{~N}_{4}$ composites and $\mathrm{Au}$ was successfully doped on monolayer $\mathrm{g}-\mathrm{C}_{3} \mathrm{~N}_{4}$. The high-resolution $\mathrm{C}$ $1 s$ spectrum in Fig. 3(b) could be fitted with two peaks at about 284.8 and $288.5 \mathrm{eV}$. The peak at $284.8 \mathrm{eV}$ corresponded to carbon contamination, and that at $288.5 \mathrm{eV}$ was assigned to the typical aromatic $\mathrm{C}-\mathrm{N}=\mathrm{C}$ motif [49]. The high-resolution $\mathrm{N} 1 \mathrm{~s}$ spectrum in Fig. 3(c) could be deconvoluted into three peaks at about $398.9,400.4$, and $401.5 \mathrm{eV}$, which were attributed to nitrogen atoms in the $\mathrm{C}=\mathrm{N}-\mathrm{C}, \mathrm{C}-\mathrm{N}(-\mathrm{C})-\mathrm{C}$, and $\mathrm{C}-\mathrm{N}-\mathrm{H}$ functional groups, respectively [50]. Based on these XPS analysis, the molecular structure of monolayer $\mathrm{g}-\mathrm{C}_{3} \mathrm{~N}_{4}$ remained unchanged after the introduction of a small amount of $\mathrm{Au}$. In addition, the high-resolution $\mathrm{Au} 4 f$ spectrum in Fig. 3(d) could be deconvoluted into two peaks at about 83.8 and $87.4 \mathrm{eV}$, which were assigned to $\mathrm{Au} 4 f_{7 / 2}$ and $\mathrm{Au} 4 f_{5 / 2}$, respectively. These values were consistent with reported literature [51], further confirming the presence of metallic $\mathrm{Au}$ in the $\mathrm{Au} /$ monolayer $\mathrm{g}-\mathrm{C}_{3} \mathrm{~N}_{4}$ composites.

The morphologies of the monolayer $\mathrm{g}-\mathrm{C}_{3} \mathrm{~N}_{4}$ and $\mathrm{Au} /$ monolayer $\mathrm{g}-\mathrm{C}_{3} \mathrm{~N}_{4}$ were observed by scanning electron microscopy (SEM) and transmission electron microscopy (TEM), as shown in Fig. 4. Fig 4(a) reveals that monolayer g- $\mathrm{C}_{3} \mathrm{~N}_{4}$ was electron transparent and its surface was wrinkled, indicating that monolayer $\mathrm{g}^{-} \mathrm{C}_{3} \mathrm{~N}_{4}$ consisted of ultrathin nanosheets with a structure like that of graphene. Fig 4(b) reveals that $1 \% \mathrm{Au} /$ monolayer $\mathrm{g}-\mathrm{C}_{3} \mathrm{~N}_{4}$ was also wrinkled, illustrating that the introduction of Au plasmonic nanoparticles did
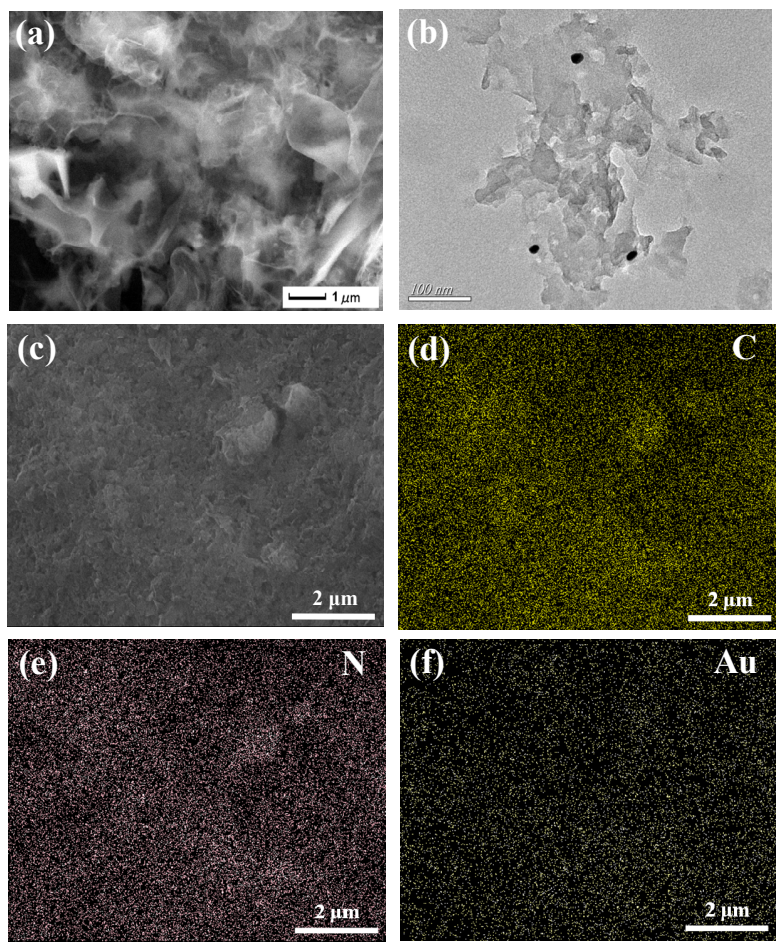

Fig. 4. (a) SEM image of monolayer g- $\mathrm{C}_{3} \mathrm{~N}_{4}$. (b) TEM image of $1 \%$ $\mathrm{Au} /$ monolayer g- $\mathrm{C}_{3} \mathrm{~N}_{4}$. (c) SEM image of $1 \% \mathrm{Au} /$ monolayer $\mathrm{g}-\mathrm{C}_{3} \mathrm{~N}_{4}$. Chemical element mapping images of $1 \% \mathrm{Au} /$ monolayer g- $\mathrm{C}_{3} \mathrm{~N}_{4} \mathrm{C} 1 s$ (d) $\mathrm{N} 1 s$ (e), and Au $4 f(\mathrm{f})$. not damage the ultrathin nanosheet structure of $\mathrm{g}-\mathrm{C}_{3} \mathrm{~N}_{4}$. Au plasmonic nanoparticles with a diameter of about $10 \mathrm{~nm}$ were dispersed on the surface of the monolayer g- $\mathrm{C}_{3} \mathrm{~N}_{4}$ nanosheets The SEM image in Fig. 4(c) of $1 \% \mathrm{Au} /$ monolayer g- $\mathrm{C}_{3} \mathrm{~N}_{4}$ further confirmed that the composite maintained its ultrathin nanosheet structure. Chemical element mapping analysis was used to confirm the existence of $\mathrm{Au}$ in the composites. As illustrated in Fig. 3(d-f), C, N, and Au were distributed in similar areas, which indicated the existence and uniform distribution of these elements. Importantly, Fig. 3(f) showed that $\mathrm{Au}$ was homogeneously distributed, further confirming the presence of $\mathrm{Au}$ plasmonic nanoparticles in the $\mathrm{Au} /$ monolayer g- $\mathrm{C}_{3} \mathrm{~N}_{4} \mathrm{com}$ posites.

The optical properties of a material greatly affect its photocatalytic activity, so the optical properties of the pure monolayer g- $\mathrm{C}_{3} \mathrm{~N}_{4}$ and $\mathrm{Au} /$ monolayer g- $\mathrm{C}_{3} \mathrm{~N}_{4}$ composites were investigated by UV-vis diffuse reflectance spectroscopy. As shown in Fig. 5, compared with the light absorption of pure monolayer g- $\mathrm{C}_{3} \mathrm{~N}_{4}$, all of the $\mathrm{Au} /$ monolayer $\mathrm{g}-\mathrm{C}_{3} \mathrm{~N}_{4}$ composites exhibited enhanced light absorption with a slight red shift. The UV-vis absorption spectra of the $\mathrm{Au} /$ monolayer $\mathrm{g}-\mathrm{C}_{3} \mathrm{~N}_{4}$ composites displayed a broad absorption peak in the range of about 500-650 nm, which was ascribed to the SPR of Au nanoparticles [51]. The absorption intensity and SPR effect obviously increased with Au content, which was related to the color of the as-prepared samples (sample color changed from white to light grey with increasing Au content). The SPR absorption improved the visible-light absorption intensity and range of the composites, thus enhancing their utilization efficiency of solar energy, which might contribute to enhanced their photocatalytic activity.

\subsection{Possible photocatalytic mechanism}

The separation, transfer, and recombination of photogenerated electron-hole pairs greatly influence the photocatalytic properties of a material, To elucidate the possible photocatalytic mechanism of the samples, photoluminescence (PL), photocurrent, and electrochemical impedance spectroscopy (EIS)

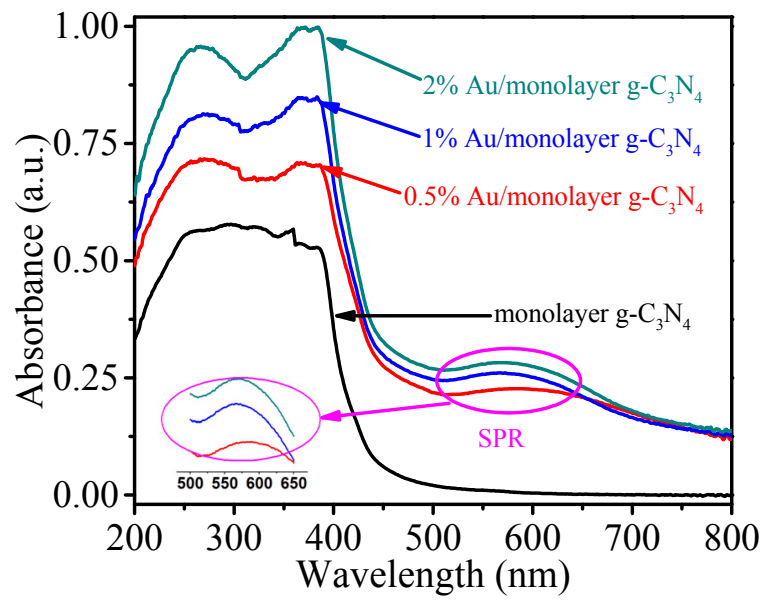

Fig. 5. Optical absorption spectra of the pure monolayer $g-\mathrm{C}_{3} \mathrm{~N}_{4}$ and $\mathrm{Au} /$ monolayer $\mathrm{g}-\mathrm{C}_{3} \mathrm{~N}_{4}$ composites. 

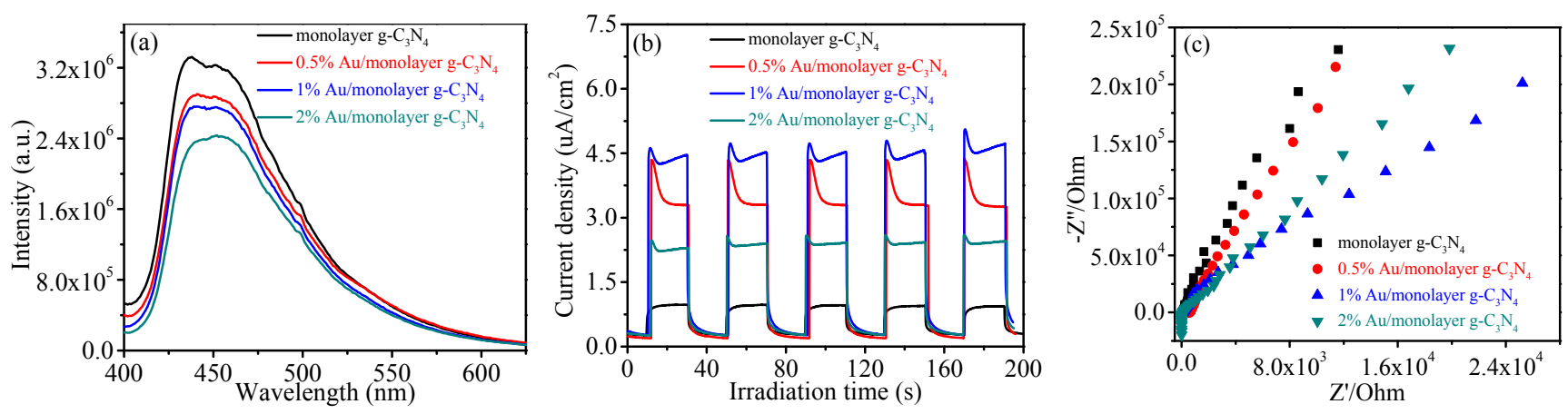

Fig. 6. (a) PL spectra of the pure monolayer g- $\mathrm{C}_{3} \mathrm{~N}_{4}$ and $\mathrm{Au} /$ monolayer g- $\mathrm{C}_{3} \mathrm{~N}_{4}$ composites. (b) Photocurrent responses of the pure monolayer g- $\mathrm{C}_{3} \mathrm{~N}_{4}$ and $\mathrm{Au} /$ monolayer g- $\mathrm{C}_{3} \mathrm{~N}_{4}$ composites under visible-light irradiation $\left(\left[\mathrm{Na}_{2} \mathrm{SO}_{4}\right]=0.1 \mathrm{~mol} / \mathrm{L}\right.$ ). (c) Nyquist plots of the pure monolayer g-C $\mathrm{C}_{3} \mathrm{~N}_{4}$ and $\mathrm{Au} /$ monolayer $\mathrm{g}-\mathrm{C}_{3} \mathrm{~N}_{4}$ composites in the dark $\left(\left[\mathrm{Na}_{2} \mathrm{SO}_{4}\right]=0.1 \mathrm{~mol} / \mathrm{L}\right)$.

measurements were performed. Fig. 6(a) displays the PL spectra of pure monolayer g- $\mathrm{C}_{3} \mathrm{~N}_{4}$ and $\mathrm{Au} /$ monolayer g- $\mathrm{C}_{3} \mathrm{~N}_{4}$ composites. The emission peaks for all samples were at the same position centered around $450 \mathrm{~nm}$, suggesting that introducing $\mathrm{Au}$ plasmonic nanoparticles did not affect the position of the emission peak of g- $\mathrm{C}_{3} \mathrm{~N}_{4}$. The PL intensity of the $\mathrm{Au} /$ monolayer g- $\mathrm{C}_{3} \mathrm{~N}_{4}$ composites was weaker than that of monolayer $\mathrm{g}-\mathrm{C}_{3} \mathrm{~N}_{4}$, indicating that the introduction of Au greatly lowered the recombination probability of photogenerated electron-hole pairs [52]. The PL results showed that introducing Au was conducive to charge separation in the $\mathrm{Au} /$ monolayer $\mathrm{g}-\mathrm{C}_{3} \mathrm{~N}_{4}$ composites, which then bring about higher photoactivity.

Next, the photocurrents of pure monolayer g- $\mathrm{C}_{3} \mathrm{~N}_{4}$ and $\mathrm{Au} /$ monolayer $\mathrm{g}-\mathrm{C}_{3} \mathrm{~N}_{4}$ composites were measured to further analyze their separation and transfer of photogenerated electron-hole pairs; the results are displayed in Fig. 6(b). The photocurrents remained stable after five intermittent on-off irradiation cycles and all the composites exhibited a higher photocurrent response than that of monolayer g- $\mathrm{C}_{3} \mathrm{~N}_{4}$. As the $\mathrm{Au}$ content increased from $0.5 \%$ to $1 \%$, the photocurrent responses gradually rose, which means that the photogenerated electron-hole pairs in the $\mathrm{Au} /$ monolayer g- $\mathrm{C}_{3} \mathrm{~N}_{4}$ composites were separated more effectively. The photocurrent response of the composites then gradually decreased as Au content increased to $2 \%$, indicating that the excess $\mathrm{Au}$ nanoparticles might be- come new recombination centers, resulting in the decline of photocatalytic activity. These results are consistent with the photocatalytic activity of the composites, explaining why $1 \%$ $\mathrm{Au} /$ monolayer $\mathrm{g}-\mathrm{C}_{3} \mathrm{~N}_{4}$ possessed the best photocatalytic performance of the composites.

To better understand the role of $\mathrm{Au}$ nanoparticles in the photocatalytic activity of the composites, EIS analysis was performed. The Nyquist plots of pure monolayer $\mathrm{g}-\mathrm{C}_{3} \mathrm{~N}_{4}$ and $\mathrm{Au} /$ monolayer g- $\mathrm{C}_{3} \mathrm{~N}_{4}$ composites are shown in Fig. 6(c). A smaller arc radius for a photocatalyst indicates more efficient charge separation and transfer [53]. All the $\mathrm{Au} /$ monolayer g- $\mathrm{C}_{3} \mathrm{~N}_{4}$ composites exhibited a smaller arc radius than that of pure monolayer g- $\mathrm{C}_{3} \mathrm{~N}_{4}$, in good agreement with the photocatalytic activities of these materials. These results illustrate that introducing $\mathrm{Au}$ to $\mathrm{g}-\mathrm{C}_{3} \mathrm{~N}_{4}$ facilitated charge separation and transfer. The arc radius of the Nyquist plot of $1 \%$ $\mathrm{Au} /$ monolayer $\mathrm{g}-\mathrm{C}_{3} \mathrm{~N}_{4}$ was the smallest of the samples, indicating that $1 \% \mathrm{Au} /$ monolayer $\mathrm{g}-\mathrm{C}_{3} \mathrm{~N}_{4}$ had the fastest charge transfer rate, which was reflected by it exhibiting the highest photocatalytic activity of the materials.

To confirm that the reason for the enhanced photocatalytic performance of the composites was hot electron injection rather than formation of a Schottky junction, the photocurrents of monolayer g- $\mathrm{C}_{3} \mathrm{~N}_{4}$ and $1 \% \mathrm{Au} /$ monolayer g- $\mathrm{C}_{3} \mathrm{~N}_{4}$ were measured under UV irradiation $(\lambda=365 \mathrm{~nm})$. As shown in Fig. $7(\mathrm{a})$,
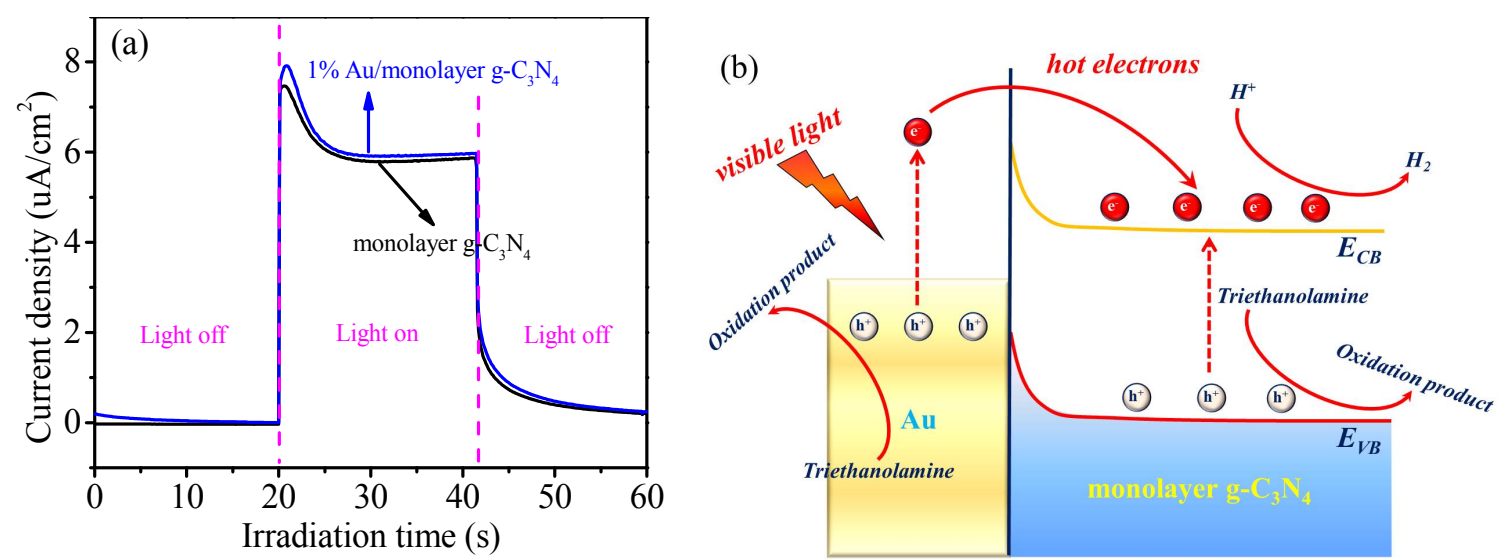

Fig. 7. (a) Photocurrent responses of the pure monolayer g- $\mathrm{C}_{3} \mathrm{~N}_{4}$ and $1 \% \mathrm{Au} / \mathrm{monolayer}$ g- $\mathrm{C}_{3} \mathrm{~N}_{4}$ under UV irradiation $(\lambda=365$ nm). (b) Schematic illustration of the proposed mechanism for photocatalytic $\mathrm{H}_{2}$ evolution over the $\mathrm{Au}$ /monolayer g- $\mathrm{C}_{3} \mathrm{~N}_{4}$ composites. 
the photocurrent intensity of $1 \% \mathrm{Au} /$ monolayer g- $\mathrm{C}_{3} \mathrm{~N}_{4}$ was nearly the same as that of monolayer $\mathrm{g}-\mathrm{C}_{3} \mathrm{~N}_{4}$ under UV light, which meant that the photogenerated electrons in the $\mathrm{CB}$ of monolayer $\mathrm{g}-\mathrm{C}_{3} \mathrm{~N}_{4}$ could not be transferred to the surface of $\mathrm{Au}$ plasmonic nanoparticles. That is, a Schottky junction did not play a part in the charge flow process. Therefore, it could be speculated that hot electron injection increased the efficiency of the whole photocatalytic process. As presented in Fig. 7(b), when the $\mathrm{Au} /$ monolayer $\mathrm{g}-\mathrm{C}_{3} \mathrm{~N}_{4}$ was exposed to visible light, a high density of hot electrons was generated in the Au plasmonic nanoparticles through the SPR effect. The hot electrons then flowed into the $\mathrm{CB}$ of monolayer $\mathrm{g}-\mathrm{C}_{3} \mathrm{~N}_{4}$ to participate in the photocatalytic reaction, resulting in increased photocatalytic activity.

Based on the above analysis results, a possible photocatalytic $\mathrm{H}_{2}$ evolution mechanism of $\mathrm{Au} /$ monolayer g- $\mathrm{C}_{3} \mathrm{~N}_{4}$ system was proposed, as presented in Fig. 7(b). Under visible-light irradiation, $\mathrm{Au}$ plasmonic nanoparticles and monolayer g- $\mathrm{C}_{3} \mathrm{~N}_{4}$ were both excited to separate electron-hole pairs. The hot electrons then transferred to the $\mathrm{CB}$ of monolayer $\mathrm{g}-\mathrm{C}_{3} \mathrm{~N}_{4}$ because of the SPR effect. Finally, the hot electrons could unite with $\mathrm{H}^{+}$ to produce $\mathrm{H}_{2}$, and the holes could react with triethanolamine to produce the oxidation product.

The possible photocatalytic mechanism of photocatalytic degradation by the $\mathrm{Au} /$ monolayer $\mathrm{g}-\mathrm{C}_{3} \mathrm{~N}_{4}$ composites is now discussed further. To reveal the main active oxygen species in the photocatalytic process, electron spin resonance (ESR) and trapping experiments were performed using $1 \%$ $\mathrm{Au} /$ monolayer g- $\mathrm{C}_{3} \mathrm{~N}_{4}$. Fig. 8(a) shows the ESR spectra of superoxide radicals $\left(\mathrm{O}_{2} \bullet^{-}\right)$. There was no ESR signal in the dark and the obvious characteristic peaks of $\mathrm{O}_{2} \bullet^{-}$were observed visible-light irradiation. These results illustrate that $\mathrm{O}_{2} \bullet-$ could only be generated when visible light reached the surface of the as-prepared sample. In contrast, no signals from hydroxyl radicals $(\bullet \mathrm{OH})$ were detected (Fig. 8(b)), which signified that $\bullet \mathrm{OH}$ was not the main active species; instead, $\mathrm{O}_{2} \bullet^{--}$played an im-
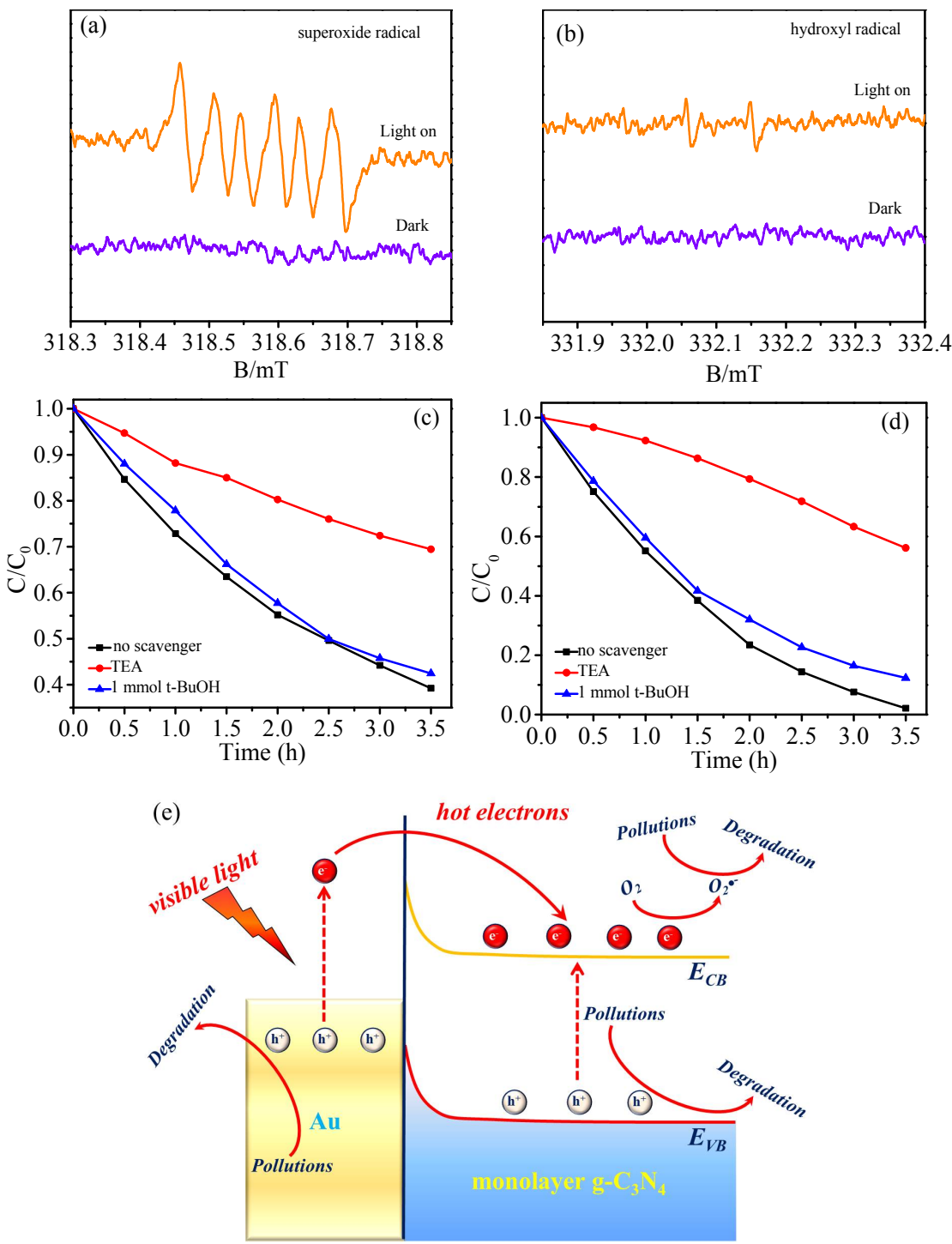

Fig. 8. ESR spectra of $1 \% \mathrm{Au} /$ monolayer g- $\mathrm{C}_{3} \mathrm{~N}_{4}$ under visible-light irradiation. (a) Superoxide radical and (b) hydroxyl radical. Trapping experiments of active species during the photodegradation of (c) CIP and (d) MO in the presence of $1 \% \mathrm{Au} / \mathrm{monolayer}_{\mathrm{g}} \mathrm{C}_{3} \mathrm{~N}_{4}$ under visible-light irradiation. (e) Schematic illustration of the proposed mechanism for photodegradation of pollutants. 
portant role in this photocatalytic reaction. Moreover, according to the results of trapping experiments in Fig. 8(c) and (d), generated holes also affected the photocatalytic degradation process. In the trapping experiments, tert-butanol was used as an $\bullet \mathrm{OH}$ scavenger and triethanolamine was used as a hole scavenger. Fig 8(c) reveals that the photodegradation efficiency of $\mathrm{CIP}$ over $1 \% \mathrm{Au} /$ monolayer $\mathrm{g}-\mathrm{C}_{3} \mathrm{~N}_{4}$ was strongly inhibited upon the addition of triethanolamine. Conversely, the photocatalytic degradation efficiency only slightly changed upon the addition of tert-butanol. Therefore, holes were another main active species and $\bullet \mathrm{OH}$ were not. The same results were found for MO photodegradation (Fig. 8(d)), which indicates that the photocatalytic mechanism might be the same for photodegradation of MO and CIP. The ESR and trapping experiments revealed that $\mathrm{O}_{2} \bullet^{-}$and holes were the main species affecting the photocatalytic activity of this system. The proposed photocatalytic degradation mechanism based on these results is presented in Fig. 8(e). Under visible-light irradiation, Au plasmonic nanoparticles and monolayer $\mathrm{g}-\mathrm{C}_{3} \mathrm{~N}_{4}$ were both excited to separate electron-hole pairs. The hot electrons were transferred to the CB of monolayer $\mathrm{g}-\mathrm{C}_{3} \mathrm{~N}_{4}$ because of the SPR effect. The hot electrons could unite with $\mathrm{O}_{2}$ to produce $\mathrm{O}_{2} \bullet-$, then $\mathrm{O}_{2} \bullet-$ reacted with pollutants. Meanwhile, the holes also could react with pollutants.

\section{Conclusions}

$\mathrm{An} \mathrm{Au} /$ monolayer g- $\mathrm{C}_{3} \mathrm{~N}_{4}$ plasmonic photocatalyst was successfully synthesized by an oil-bath method. The $\mathrm{Au} /$ monolayer $\mathrm{g}-\mathrm{C}_{3} \mathrm{~N}_{4}$ composites exhibited enhanced photocatalytic activity compared with that of monolayer g- $\mathrm{C}_{3} \mathrm{~N}_{4}$ and $1 \% \mathrm{Au} /$ monolayer $\mathrm{g}-\mathrm{C}_{3} \mathrm{~N}_{4}$ possessed the highest photocatalytic performance. The enhanced photocatalytic activity was chiefly attributed to the SPR effect of the Au nanoparticles, which promoted ultrafast hot electron transfer from $\mathrm{Au}$ plasmonic nanoparticles into the $\mathrm{CB}$ of monolayer $\mathrm{g}-\mathrm{C}_{3} \mathrm{~N}_{4}$, inducing higher transfer and separation efficiencies of the photogenerated electron-hole pairs.

\section{References}

[1] T. Bhowmik, M. K. Kundu, S. Barman, ACS Catal, 2016, 6, 1929-1941.

[2] G. G. Liu, T. Wang, H. B. Zhang, X. G. Meng, D. Hao, K. Chang, P. Li, T. Kako, J. H. Ye, Angew. Chem. Int. Ed., 2015, 54, 13561-13565.

[3] R. G. Li, Chin. J. Catal., 2017, 38, 5-12.

[4] X. Tan, H. A. Tahini, S. C. Smith, ACS Catal., 2016, 6, 7071-7077.

[5] G. G. Liu, G. X. Zhao, W. Zhou, Y. Y. Liu, H. Pang, H. B. Zhang, D. Hao, X. G. Meng, P. Li, T. Kako, J. H. Ye, Adv. Funct. Mater., 2016, 26, 6822-6829.

[6] K. L. Corp, C. W. Schlenker, J. Am. Chem. Soc., 2017, 139, 7904-7912.

[7] Q. Han, B. Wang, J. Gao, L. T. Qu, Angew. Chem. Int. Ed., 2016, 55, 10849-10853.

[8] H. Ahmad, S. K. Kamarudin, L. J. Minggu, M. Kassim, Renewable

\section{Graphical Abstract}

Chin. J. Catal., 2018, 39: 760-770 doi: 10.1016/S1872-2067(17)62978-4

\section{Gold/monolayer graphitic carbon nitride plasmonic photocatalyst for ultrafast electron transfer in solar-to-hydrogen energy conversion}

Zhao Mo, Hui Xu*, Zhigang Chen, Xiaojie She, Yanhua Song, Pengcheng Yan, Yuanguo Xu, Yucheng Lei*, Shouqi Yuan, Huaming Li * Jiangsu University; Jiangsu University of Science and Technology
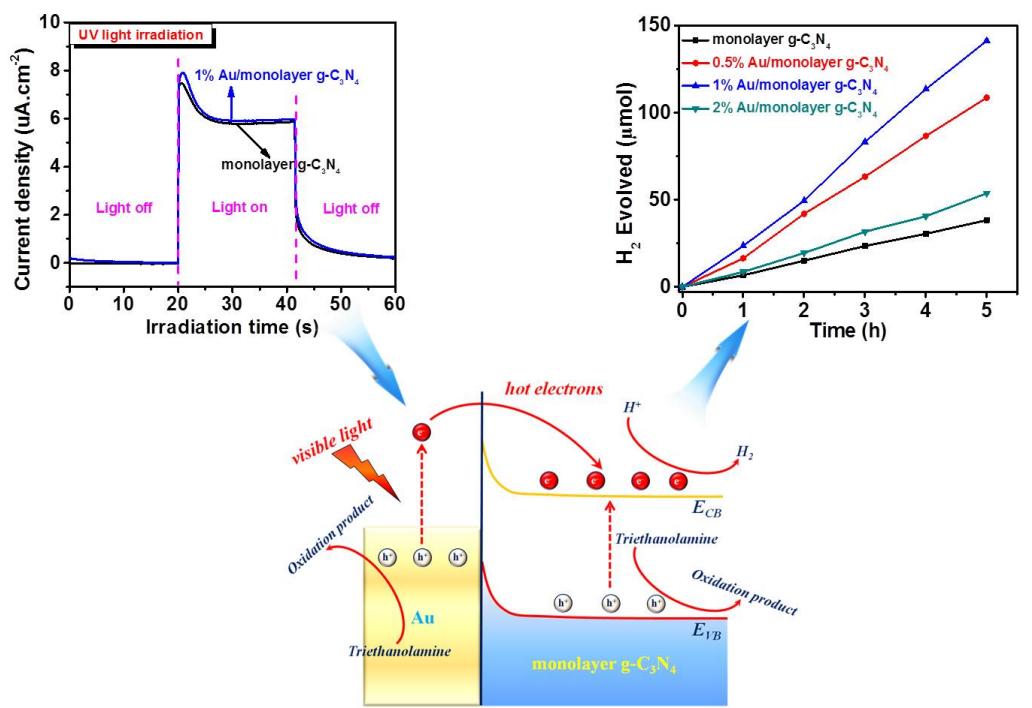

A gold nanoparticle/monolayer graphitic carbon nitride plasmonic photocatalyst prepared by a facile oil-bath method displayed a high photocatalytic hydrogen evolution rate of $565 \mu \mathrm{mol} \mathrm{g}^{-1} \mathrm{~h}^{-1}$ because of the regulated flow of charge carriers. 
Sustainable Energy Rev., 2015, 43, 599-610.

[9] L. Yuan, C. Han, M. Q. Yang, Y. J. Xu, Int. Rev. Phys. Chem., 2016, 35, 1-36.

[10] K. Maeda, K. Domen, Bull. Chem. Soc. Jpn., 2016, 89, 627-648.

[11] G. G. Zhang, Z. A. Lan, X. C. Wang, Chem. Sci., 2017, 7, 3062-3066.

[12] G. P. Dong, Y. H. Zhang, Q. W. Pan, J. R. Qiu, J. Photochem. Photobiol. C, 2014, 20, 33-50.

[13] Y. F. Li, R. X. Jin, Y. Xing, J. Q. Li, S. Y. Song, X. C. Liu, M. Li, R. C. Jin, Adv. Energy Mater., 2016, 6, 1601273.

[14] Y. H. Li, W. K. Ho, K. L. Lv, B. C. Zhu, S. C. Lee, Appl. Surf. Sci., 2018, 430, 380-389.

[15] X. P. Dong, F. X. Cheng, J. Mater. Chem. A, 2015, 3, 23642-23652.

[16] W. J. Ong, L. L. Tan, Y. H. Ng, S. T. Yong, S. P. Chai, Chem. Rev., 2016, 116, 7159-7329.

[17] C. M. Li, Y. H. Du, D. P. Wang, S. M. Yin, W. G. Tu, Z. Chen, M. Kraft, G. Chen, R. Xu, Adv. Funct. Mater., 2017, 27, 1604328.

[18] H. J. Yu, R. Shi, Y. X. Zhao, T. Bian, Y. F. Zhao, C. Zhou, G. I. N. Waterhouse, L. Z. Wu, C. H. Tung, T. R. Zhang, Adv. Mater., 2017, 29, 70111.

[19] J. S. Zhang, Y. Chen, X. C. Wang, Energy Environ. Sci., 2015, 8, 3092-3108.

[20] S. W. Cao, J. X. Low, J. G. Yu, M. Jaroniec, Adv. Mater., 2015, 27, 2150-2176.

[21] G. Mamba, A. K. Mishra, Appl. Catal. B, 2016, 198, 347-377.

[22] Y. H. Li, K. L. Lv, W. K. Ho, F. Dong, X. F. Wu, Y. Xia, Appl. Catal. B, 2017, 202, 611-619.

[23] X. J. She, J. J. Wu, J. Zhong, H. Xu, Y. C. Yang, R. Vajtai, J. Lou, Y. Liu, D. L. Du, H. M. Li, P. M. Ajayan, Nano Energy, 2016, 27, 138-146.

[24] S. M. Yin, J. Y. Han, T. H. Zhou, R. Xu, Catal. Sci. Technol., 2015, 5, 5048-5061.

[25] Q. Han, B. Wang, J. Gao, Z. H. Cheng, Y. Zhao, Z. P. Zhang, L. T. Qu, ACS Nano, 2016, 10, 2745-2751.

[26] Z. W. Zhao, Y. J. Sun, F. Dong, Nanoscale, 2015, 7, 15-37.

[27] S. J. Tan, L. M. Liu, Y. N. Dai, J. D. Ren, J. Zhao, H. Petek, J. Am. Chem. Soc., 2017, 139, 6160-6168.

[28] U. Bhattacharjee, L. Men, B. A. Rosales, S. R. Alvarado, J. Vela, J. W. Petrich, J. Phys. Chem. C, 2017, 121, 676-683.

[29] T. T. Wang, P. Raghunath, Y. G. Lin, M. C. Lin, J. Phys. Chem. C, 2017, 121, 9681-9690.

[30] Y. H. Li, K. L. Lv, W. K. He, Z. W. Zhao, Y. Huang, Chin. J. Catal., 2017, $38,321-329$.

[31] C. C. Jia, X. X. Li, N. Xin, Y. Gong, J. X. Guan, L. N. Meng, S. Meng, X. F. Guo, Adv. Energy Mater., 2016, 6, 1600431.
[32] M. Valenti, M. P. Jonsson, G. Biskos, A. Schmidt-Ott, W. A. Smith, J. Mater. Chem. A, 2016, 4, 17891-17912.

[33] J. W. Hong, D. H. Wi, S. U. Lee, S. W. Han, J. Am. Chem. Soc., 2016, $138,15766-15773$.

[34] X. G. Meng, L. Q. Liu, S. X. Ouyang, H. Xu, D. F. Wang, N. Q. Zhao, J. H. Ye, Adv. Mater., 2016, 28, 6781-6803.

[35] L. Yan, F. W. Wang, S. Meng, ACS Nano, 2016, 10, 5452-5458.

[36] J. M. Zhang, X. Jin, P. I. Morales-Guzman, X. Yu, H. Liu, H. Zhang, L. Razzari, J. P. Claverie, ACS Nano, 2016, 10, 4496-4503.

[37] S. Bai, X. Y. Li, Q. Kong, R. Long, C. M. Wang, J. Jiang, Y. J. Xiong, $A d v$. Mater., 2015, 27, 3444-3452.

[38] A. Naldoni, T. Montini, F. Malara, M. M. Mróz, A. Beltram, T. Virgili, C. L. Boldrini, M. Marelli, I. Romero-Ocaña, J. J. Delgado, V. Dal Santo, P. Fornasiero, ACS Catal., 2017, 7, 1270-1278.

[39] S. K. Cushing, N. Wu, J. Phys. Chem. Lett., 2016, 7, 666-675.

[40] J. J. Yi, X. J. She, Y. H. Song, H. Xu, P. Zhang, Z. Mo, L. Liu, D. L. Du, H. M. Li, RSC Adv., 2016, 6, 112420-112428.

[41] S. Tonda, S. Kumar, V. Shanker, Mater. Res. Bull., 2016, 75, 51-58.

[42] X. J. Bai, R. L. Zong, C. X. Li, D. Liu, Y. F. Liu, Y. F. Zhu, Appl. Catal. B, 2014, 147, 82-91.

[43] L. Ge, C. C. Han, J. Liu, Y. F. Li, Appl. Catal. A, 2011, 409-410, 215-222.

[44] H. Xu, J. Yan, Y. G. Xu, Y. H. Song, H. M. Li, J. X. Xia, C. J. Huang, H. L. Wan, Appl. Catal. B, 2013, 129, 182-193.

[45] N. Y. Cheng, J. Q. Tian, Q. Liu, C. J. Ge, A. H. Qusti, A. M. Asiri, A. O. Al-Youbi, X. P. Sun, ACS Appl. Mater. Interfaces, 2013, 5, 6815-6819.

[46] X. J. She, H. Xu, H. F. Wang, J. X. Xia, Y. H. Song, J. Yan, Y. G. Xu, Q. Zhang, D. L. Du, H. M. Li, Dalton Trans., 2015, 44, 7021-7031.

[47] Z. Mo, X. J. She, Y. P. Li, L. Liu, L. Y. Huang, Z. G. Chen, Q. Zhang, H. Xu, H. M. Li, RSC Adv., 2015, 5, 101552-101562.

[48] H. Xu, J. Yan, X. J. She, L. Xu, J. X. Xia, Y. G. Xu, Y. H. Song, L. Y. Huang, H. M. Li, Nanoscale, 2014, 6, 1406-1415.

[49] Z. X. Zhou, J. H. Wang, J. C. Yu, Y. F. Shen, Y. Li, A. R. Liu, S. Q. Liu, Y. J. Zhang, J. Am. Chem. Soc., 2015, 137, 2179-2182.

[50] H. Xu, Y. X. Song, Y. H. Song, J. X. Zhu, T. T. Zhu, C. B. Liu, D. X. Zhao, Q. Zhang, H. M. Li, RSC Adv., 2014, 4, 34539.

[51] J. J. Xue, S. S. Ma, Y. M. Zhou, Z. W. Zhang, M. He, ACS Appl. Mater. Interfaces, 2015, 7, 9630-9637.

[52] K. L. He, J. Xie, X. Y. Luo, J. Q. Wen, S. Ma, X. Li, Y. P. Fang, X. C. Zhang, Chin. J. Catal., 2017, 38, 240-252.

[53] F. Chen, H. Yang, X. F. Wang, H. G. Yu, Chin. J. Catal., 2017, 38, 296-304.

\title{
具有超快电子传输能力的金/薄层氮化碳等离子光催化剂用于光催化产氢
}

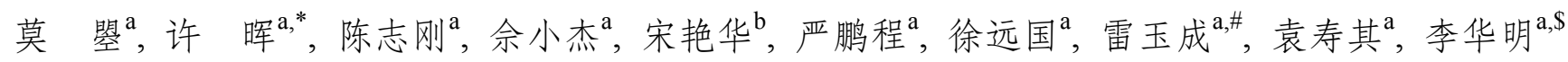 \\ a 江苏大学材料科学与工程学院, 能源研究院, 江苏镇江 212003 \\ b江苏科技大学环境与化工学院, 江苏镇江 212003
}

摘要: 光催化产氢可以直接将太阳能转化为化学能, 是非常有前景的产氢技术之一. 然而, 光催化产氢的瓶颈在于如何提 高光催化产氢效率和光催化剂的稳定性, 以及降低产氢成本. 因此, 开发廉价、易于制备的产氢光催化剂引起人们广泛关 注. 作为一种非金属半导体光催化剂, 石墨相氮化碳 $\left(\mathrm{g}-\mathrm{C}_{3} \mathrm{~N}_{4}\right)$ 具有良好的物理化学性质, 如良好的化学和热稳定性、极佳的 光电性能、强的抗氧化能力等. 更为重要的是, $g-C_{3} N_{4}$ 具有合适的能带结构, 能够利用可见光. 因此, $g-C_{3} N_{4}$ 已广泛应用于光 催化降解、空气净化、光解水和光催化 $\mathrm{CO}_{2}$ 还原等领域. 然而, 体相 $g-\mathrm{C}_{3} \mathrm{~N}_{4}$ 仍然暴露出一些缺点, 例如比表面积小、光生电 子-空穴对的复合率高和反应动力学差等. 将体相 $\mathrm{g}-\mathrm{C}_{3} \mathrm{~N}_{4}$ 剥离成 $\mathrm{g}-\mathrm{C}_{3} \mathrm{~N}_{4}$ 纳米薄片是提高光催化效率的有效方法. 薄层 g- $\mathrm{C}_{3} \mathrm{~N}_{4}$ 纳米片具有较高的比表面积, 比体相的 $\mathrm{g}-\mathrm{C}_{3} \mathrm{~N}_{4}$ 有更好的光生电子-空穴对分离效率.

为了进一步提高 $\mathrm{g}-\mathrm{C}_{3} \mathrm{~N}_{4}$ 的光催化性能, 本文通过在薄层 $\mathrm{g}-\mathrm{C}_{3} \mathrm{~N}_{4}$ 表面均匀分散 $\mathrm{Au}$ 纳米颗粒来控制电荷载流子的流动. 并 
通过光催化产氢和污染物降解来评估金/薄层氮化碳 (Au/monolayer $g-\mathrm{C}_{3} \mathrm{~N}_{4}$ )复合材料的光催化性能. 所有的 $\mathrm{Au} /$ / 薄层 $\mathrm{g}-\mathrm{C}_{3} \mathrm{~N}_{4}$ 复合材料均显示出优于体相 $\mathrm{g}-\mathrm{C}_{3} \mathrm{~N}_{4}$ 的光催化性能, 其中 $1 \% \mathrm{Au}$ 薄层 $\mathrm{g}-\mathrm{C}_{3} \mathrm{~N}_{4}$ 复合光催化剂具有最高的产氢速率 $(565 \mu \mathrm{mol} \mathrm{g}$ $\mathrm{h}^{-1}$ ), 且具有最佳的污染物降解能力. 这主要归结于热电子的注入, 而不是肖特基结. Au纳米颗粒的成功引入带来了表面等 离子共振 (SPR)效应, SPR 效应不仅能够提高光吸收效率, 而且能够带来高效的热电子转移途径. 热电子是从Au纳米颗粒表 面注入到薄层 $\mathrm{g}-\mathrm{C}_{3} \mathrm{~N}_{4}$ 纳米片的导带上. 因此, $\mathrm{Au} /$ 薄层 $\mathrm{g}-\mathrm{C}_{3} \mathrm{~N}_{4}$ 复合光催化剂具有更高的光生电子-空穴对迁移和分离效率, 以及更低的光生电子-空穴对复合几率.

采用紫外可见光谱 $(U V-V i s) 、$ 光致发光光谱 $(P L)$ 、光电流和阻抗等表征手段研究了 $A u$ 薄层 $g-C_{3} N_{4}$ 复合光催化剂性能 提升的原因. 结果表明, 相比于薄层 $\mathrm{g}-\mathrm{C}_{3} \mathrm{~N}_{4}$ 纳米片, $\mathrm{Au}$ /薄层 $\mathrm{g}-\mathrm{C}_{3} \mathrm{~N}_{4}$ 复合光催化剂具有更好的光电性能, 因而光催化活性更 高. 此外, 与薄层 $\mathrm{g}-\mathrm{C}_{3} \mathrm{~N}_{4}$ 纳米片的光电流强度相比, $\mathrm{Au} /$ 薄层 $\mathrm{g}-\mathrm{C}_{3} \mathrm{~N}_{4}$ 复合光催化剂的光电流强度没有发生改变, 这表明薄层 $\mathrm{g}-\mathrm{C}_{3} \mathrm{~N}_{4}$ 纳米片导带上的光生电子不可能转移到 $\mathrm{Au}$ 纳米颗粒的表面. 也就是说, 肖特基结并没有参与到电子转移过程中, 因 此推测出整个光催化反应是热电子注入在起作用.

关键词: 单层氮化碳; 金等离子纳米颗粒; 光催化产氢; 热电子; 金/单层氮化碳

收稿日期: 2017-11-30. 接受日期: 2017-12-31. 出版日期: 2018-04-05.

*通讯联系人. 电话/传真: (0511)88799500; 电子信箱: xh@ujs.edu.cn

\#通讯联系人. 电话/传真: (0511)88799500; 电子信箱: yclei@ujs.edu.cn

\$通讯联系人. 电话/传真: (0511)88799500; 电子信箱: lihm@ujs.edu.cn

基金来源：国家自然科学基金(21476097，21776118); 江苏省六大人才高峰项目(2014-JNHB-014); 江苏省自然科学基金 (BK20161363); 江苏省研究生培养创新工程(KYCX17-1769); 江苏高校优势学科建设资助项目.

本文的电子版全文由Elsevier出版社在ScienceDirect上出版(http://www.sciencedirect.com/science/journal/18722067). 